European Journal of Pragmatism and American Philosophy

VIII-1 | 2016

Dewey's Democracy and Education as a Source of and a Resource for European Educational Theory and Practice

\title{
A Supplement Instead of a Completion
}

\section{Lucia Santaella}

\section{(2) OpenEdition \\ Journals}

Electronic version

URL: http://journals.openedition.org/ejpap/460

DOI: $10.4000 /$ ejpap.460

ISSN: 2036-4091

Publisher

Associazione Pragma

Electronic reference

Lucia Santaella, «A Supplement Instead of a Completion », European Journal of Pragmatism and American Philosophy [Online], VIII-1 | 2016, Online since 20 July 2016, connection on 19 April 2019 URL : http://journals.openedition.org/ejpap/460 ; DOI : 10.4000/ejpap.460

This text was automatically generated on 19 April 2019.

\section{c) $(7)(9)$}

Author retains copyright and grants the European Journal of Pragmatism and American Philosophy right of first publication with the work simultaneously licensed under a Creative Commons AttributionNonCommercial-NoDerivatives 4.0 International License. 


\title{
A Supplement Instead of a Completion
}

\author{
Lucia Santaella
}

1 The thesis defended in Giovanni Maddalena's book, The Philosophy of Gesture. Completing Pragmatists' Incomplete Revolution, ${ }^{1}$ is that the pragmatist project represents a sound way to face the Kantian dilemmas. However, this project was incomplete and to overcome this gap, the author builds the concept of "complete gesture," based more particularly on the phenomenology and semiotics of C. S. Peirce. In addition to being well-built, the concept is inspiring, and this is clearly demonstrated in its applications in the fields of identity, creativity, morality, and education. However, I find it difficult to accept Maddalena's finding that the Peircean project is incomplete, and I will try to provide some arguments to support this contention. My arguments take as their starting point the fact that, to fully understand Peirce's mature pragmatism, one must take into thorough account that it only makes sense in its connection to his normative sciences: logic, ethics, and aesthetics (CP 8.255, EP2: 334-5).

2 The concern with ethics occupied Peirce's entire life. However, until the end of the 1880s, he failed to consider ethics as a theoretical science, but only as an art or a practical science. This consideration has changed, on the one hand, because his logic of relatives led him to the conclusion that logic is not self-sufficient. On the other hand, when trying to distinguish pure ethics from morality, he saw the importance of theoretical ethics, and began to suspect a much deeper connection between ethics and logic. In reviewing his pragmatism of 1877-78, Peirce emphasized the role of self-control in logical thinking, postulating, in 1901, that ethics is the foundation of logic. A year later, he would posit that ethics, in turn, is based on aesthetics, this fitting the search of the supreme ideal, summum bonum of human life.

With the normative sciences, Peirce was rethinking the aims, purposes, values, goals and ideals that attract and guide our deliberate conduct. Although he used the traditional names, aesthetics, ethics and logic, Peirce sought to give them original meanings. For $\mathrm{him}$, logic takes care of reasoning as a deliberate activity, aiming to discriminate good and bad ways of thinking. It critically establishes the rules that must be followed by 
reason, but it needs to appeal to the purpose or goal that justifies these rules. "Logic is the study of the means to achieve the goal of thought, but it is ethics that defines the goal" (CP 2.198). The fundamental problem of ethics is not what is right or wrong, but what we are deliberately prepared to accept as an affirmation of what we should do, of what we have in view, of what we seek. Where should the force and effort of our will be directed to? To find out what would be the nature of this seduction or ultimate force of attraction in its purity is what Peirce came to regard as the purpose of aesthetics.

Thus, the indissoluble links between the three normative sciences are expressed as follows: human action is reasoned action, which, in turn, is deliberate and controlled. But all deliberate and controlled action is guided by purposes, goals, which, in turn, should be chosen. This choice also, if the result of reason must be deliberate and controlled, which, after all, requires the recognition of something that is admirable in itself to be desired. Logic as the study of correct reasoning is the science of the means to act reasonably. Ethics helps and guides logic by examining the purposes for which those ends should be addressed. Finally, aesthetics guides ethics since it defines the nature of an end in itself that is admirable and desirable in all circumstances regardless of any other consideration of any kind whatsoever. Ethics and logic are therefore specifications of aesthetics. Ethics proposes what purposes should reasonably be chosen under various circumstances, while logic suggests what means are available to pursue these purposes.

The ideal that Peirce had in mind is the ultimate end toward which human effort must be directed. This is the most supreme ideal on which our desire, will and sentiments should be focused. The ideal of the ideal, the summum bonum, which needs no justification and explanation. What could be this goal that, without ignoring that the outside world produces inevitable interferences in the agent's mind and will, still incorporates the free development of the agent at the same time that ensures that this freedom will not be troubled by unpredictable and unavoidable events in the long run? Furthermore, and most importantly, the quality that attracts the agent's free development should be the counterpart of an overall aesthetic quality whose other side is the ultimate action that experience exerts on him/her.

6 The critical review of pragmatism had led Peirce to consider, first, that the pragmatic ideal should not satisfy the desires of any particular individual, but had to face collective human purposes. To answer this demand and fulfill the requirement of being a completely satisfying goal, the ideal should be evolutionary, with its complete significance located in the distant future always concretely postponed. An ideally thinkable future, but materially unattainable because only asymptotically approachable. Pragmatism had discovered that, in the process of evolution, that which exists, more and more, embodies certain classes of ideals that in the course of development show to be reasonable. This ideal was then characterized as "the continual increase of the embodiment of the idea potentiality" (MS 283: 103; EP2: 388, 1906).

7 As I have already explained some years ago (2001: 197-8), within our minds, ideas are transmitted from one point to another in time by means of thought, that is, by means of immaterial or imaginary signs, as Kent (1987: 158) prefers to call them. But ideas are not yet embodied thoughts, they are "some potentiality, some form, which may be embodied in external or in internal signs" (MS 283: 4). Moreover, the aim of the sign can only be accomplished in the growth of the idea's potentiality, when its embodiment occurs not only by means of symbols but also through actions, habits and changes of habits. In potentiality there is firstness; in the embodiment in signs, there is secondness; and in the 
idea there is thirdness, the principle of continuity. The three together compose what Peirce began to consider as the aesthetic summum bonum, which coincides with the ultimate pragmatist ideal: the growth of concrete reasonableness. This ideal should take into consideration the role of self-control in the acquisition of new habits as the method through which the pragmatic ideal may be attained.

8 Since reason is the only quality which is freely developed through the human activity of self-control, in other words, as the essence of rationality is in self-criticism and heterocriticism, Peirce identified the aesthetic ideal, the ultimate ideal of pragmaticism, with the growth of concrete reasonableness. It cannot be confused either with abstract reasonableness lost in the fog of incorporeal ideals, or with static reasonableness, which, like everything that is static, ends up in oppression. On the contrary, it means reasonableness in constant development, in process, and in transformation. The only thing that is desirable without any ulterior reason, at any time and in any place whatsoever, is to present ideas that are reasonable. Hence we are responsible for the achievement and enlargement of concrete reasonableness; it is by means of our embodied feelings, deeds, and thoughts that reason becomes concrete, heading toward an open end whose destiny we are unable to know in advance.

Reasonableness has no similarity with any form of rationalism, since it refers to a kind of rationality which embodies elements of action and feeling, and incorporates all their mixtures which appear in affection, pleasure, wish, will, desire, commotion, and emotion. Peirce was conscious that there is no a priori guarantee that the aesthetic ideal can be attained. The only rule of ethics is to adhere to the ideal and to expect that it can be approached gradually and in a long course of time (Bernstein 1990). Since deliberate conduct is conduct guided by the aesthetic ideal, human thoughts, actions and feelings should be evaluated in terms of their contribution to the growth of concrete reasonableness in the world (Curley 1969: 103-4). Concrete indicates that reasonableness may be gradually updated by means of our resolute effort toward favoring its growth. This effort is ethical. It is the way by which the goal of the aesthetic ideal is materialized. Likewise, logic is the means through which the ethical goal is embodied (Santaella 1994).

10 As far as I can see, this development of Peirce's pragmaticism does not match Maddalena's statement that in the Monist series (1905-06), Peirce "tried in vain to fully explain" the order that he had in mind (32). It is also dismissive of Maddalena's claim that Peirce did not complete the view that "ethics and aesthetics judge reality from a cognitive point of view" (138).

11 Unlike this gap, Maddalena is much closer to Peirce than he imagines, when he builds the concept of complete gesture as "any perfomed act with a beginning and an end that carries a meaning" (69), and when he states that complete gestures follow

the admirable ideal to the extent that they help any particular to achieve the meaning of its own continuum of tradition and purpose. But the real aim of any complete gesture is to push any particular to fit, and thereby to help grow reality as such, passing from embodiment to embodiment, which are the different steps of our synthetic comprehension of reality. (101)

12 From this, what I can conclude is that Maddalena's argumentative trajectory to reach his conclusions, although inspired by Peirce, is distinct from the path used by Peirce. However, the conclusions to which they arrive are very similar. Hence instead of filling Peirce's incompleteness, Maddalena, in fact, found a different route with precious 
applications to enrich our understanding of pragmaticism and its extreme relevance to the contemporary ethical debate.

\section{BIBLIOGRAPHY}

BERNSTEIN R., (1990), “A sedução do ideal,” Face, 3, 2, 195-206.

CURLEY T., (1969), “The Relation of the Normative Sciences to Peirce's Theory of Inquiry,”

Transactions of the Charles S. Peirce Society, 5, 2, 91-106.

KENT B., (1987), Logic and the Classification of the Sciences, Montreal, McGill-Queen's University

Press.

PEIRCE C. S., (1931-1958), Collected Papers, 8 vols, Charles Hartshorne, Paul Weiss, and A. W. Burks, Cambridge, MA., Harvard University Press. Designated as CP.

PEIRCE C. S., Unpublished Manuscripts, numbered and paginated by the Institute for Studies in Pragmaticism, Texas Tech University, Lubbock, Texas. Designated as MS.

PEIRCE C. S., (1998), Essential Peirce 2, edited by the Peirce Edition Project, Bloomington \& Indiana, Indiana University Press. Designated as EP2.

SANTAella L., (1994), Estética de Platão a Peirce, São Paulo, Experimento.

SANTAella L., (2001), “Esthetics, the Supreme Ideal of Human Life," Semiotica, 135, 1/4, 175-89.

\section{NOTES}

1. All references, if not otherwise noted, will be to Maddalena 2015.

\section{AUTHOR}

\section{LUCIA SANTAELLA}

Pontifícia Universidade Católica de São Paulo

lbraga[at]pucsp.br 